\title{
Evaluation of Groundwater Quality for Heavy Metals by Using Chemical Indices Approach in Karachi, Pakistan
}

\author{
Aziz Ur Rahman ${ }^{1}$, Haq Nawaz Abbasi ${ }^{2}$, and Muhammad Owais ${ }^{3}$ \\ ${ }^{1 *}$ Department of Chemistry, Government Degree Boys College, 5-L, New Karachi, Karachi, Pakistan. \\ ${ }^{2}$ Department of Environmental Science, Federal Urdu University, Karachi, Pakistan. \\ ${ }^{3}$ Department of Energy and Environment, Hamdard University, Karachi, Pakistan. \\ *Corresponding Author Email: azizemaz@yahoo.com \\ Received 17 May 2021, Revised 18 October 2021, Accepted 04 November 2021
}

\begin{abstract}
Freshwater consumption has been increased because of population growth and economic development. At the same time, depletion and contamination of groundwater is subject of great concern. Karachi is the industrial hub and serves as the economic backbone of Pakistan. The research aims to investigate the heavy metal pollution in the groundwater of Korangi Industrial Area, one of the largest industrial estates in Karachi. Eighteen representative locations were selected to collect groundwater samples and study the concentrations of heavy metals $\mathrm{Cr}, \mathrm{Fe}, \mathrm{Ni}$, $\mathrm{Cu}, \mathrm{Zn}$, and $\mathrm{Pb}$. Pollution load index, Nemerow's pollution index, and geo accumulation index approaches were used to interpret the basic data. The average concentrations of the measured heavy metals were $354.67 \mu \mathrm{g} . \mathrm{L}^{-1}, 694.33 \mu \mathrm{g} . \mathrm{L}^{-1}, 39.2 \mu \mathrm{g} . \mathrm{L}^{-1}, 12.89 \mu \mathrm{g} . \mathrm{L}^{-1}, 9.5 \mu \mathrm{g} . \mathrm{L}^{-1}$, and 6.17 $\mu \mathrm{g} . \mathrm{L}^{-1}$ for $\mathrm{Fe}, \mathrm{Zn}, \mathrm{Cu}, \mathrm{Pb}, \mathrm{Cr}$, and $\mathrm{Ni}$, respectively. The results showed that groundwater quality in the study area is poor and mainly contaminated by $\mathrm{Pb}$ and $\mathrm{Fe}$.
\end{abstract}

Keywords: Geo accumulation index, Heavy metals, Industrial effluent, Korangi industrial estate, Nemerow's pollution index, Pollution load index.

\section{Introduction}

Water is essential for all living creatures, and proper management of this renewable natural resource is a key aspect of sustainable development [1]. Groundwater resources are unevenly distributed and are under stress because of natural and anthropogenic factors [2]. There is a need to develop more sustainable practices and monitoring systems to protect these resources. The consumptive uses of groundwater for domestic, agriculture, and industrial sectors put huge pressure on natural systems in terms of quality and quantity [3]. Although, the groundwater resources are less vulnerable and protected by unsaturated zone or topsoil [4]. However, groundwater becomes vulnerable in areas with high population density, industrial and agriculture practices, and intensive human use of the land. Industrial activities have the potential to contaminate groundwater bodies by releasing chemicals or wastes into the environment, either intentionally or unintentionally [5].

Heavy metals pollution is a wellknown worldwide problem because of its toxicity, bioaccumulation, and environmental persistence [6]. Their discharge in water bodies can destroy the aquatic biota or transfer to humans through the food chain.

There are numerous potential sources of groundwater pollution, so it is often hard to 
find the exact source of pollutants. Regarding heavy metal pollution, industrial wastewater is the major source of groundwater contamination [7]. Ignoring and mismanagement to handle industrial effluent is the most significant environmental problem, especially in the developing countries of the world [8]. In several megacities of developing countries, industrial waste is discarded into the soil and water bodies indiscriminately without considering the after-effects [9]. The story is not different in the case of the city of Karachi.

Over the last few decades, population and demographic distribution in Karachi have been changed dramatically. According to the 2017 census current population of Karachi is around 16 million, and nearly 5 million people live in slum areas without proper sanitation systems [10]. The city is a commercial and financial hub, plays an important role in the country's economy. Karachi has built several industrial zones such as Bin Qasim Industrial Zone, Federal B Industrial Area, Karachi Export Processing Zone, Korangi Creek Industrial Park, North Karachi Industrial Area, Pakistan Textile City, S.I.T.E Industrial Area, West Wharf Industrial Area, and Korangi Industrial Area.

Korangi industrial estate (KIE), Karachi is one of the biggest industrial estates (8500 acres) in Pakistan. This estate has been in operation since 1970. Two hundred thousand to three hundred thousand employees work in this industrial estate. It generates a revenue of Rs. 270 million per day. This industrial estate serves as the pillar of Pakistan's economy.

Anthropogenic sources of pollution and their impact on groundwater are reported from different areas of Karachi [11-15]. This will further intensify the demand for potable water for the city. This is also reflected in industrial effluent infiltrations worldwide.
Groundwater pollution due to heavy metal ion contamination of the Korangi Industrial area (KIA) is reported as a burning issue by earlier researchers [16, 17]. The presence of industrial zone and demand for fresh water is equally important; therefore, it is necessary to check and monitor the wastewater discharge in terms of its quality to protect the groundwater contamination. The current study evaluates the groundwater quality regarding heavy metals in and around the groundwaters of KIE by using chemical indices approaches.

\section{Materials and Methods Study Area}

The study area (KIA) is situated in Korangi District, Karachi, Pakistan lied between $24^{\circ}, 83^{\prime}$ to $24^{\circ}, 84^{\prime} \mathrm{N}$ and $67^{\circ}, 1^{\prime}$ to $67^{\circ}, 11^{\prime} \mathrm{E}$ (Fig. 1). KIA is one of the major industrial areas and hosts almost 4500 industries, trading, and commercial units, including textile, pharmaceutical, chemical, steel, automobile, etc.

\section{Sampling Approach}

Eighteen representing points in the study area were selected for groundwater samples. One-litre polyethylene bottles were used to obtain samples. Samplings were done carefully to avoid any deterioration of water quality. The bottles were washed and rinsed with distilled and groundwaters before being used. The samples were acidified immediately with $1.5 \mathrm{~mL}$ concentrated nitric acid for metal preservation.

\section{Trace Metal Analysis}

The techniques stated in the book "Standard Methods for the Examination of Water and Wastewater" [18] for heavy metals were followed, and the instrument was spectrophotometer DR - 2800 UV VIS, HACH USA. 


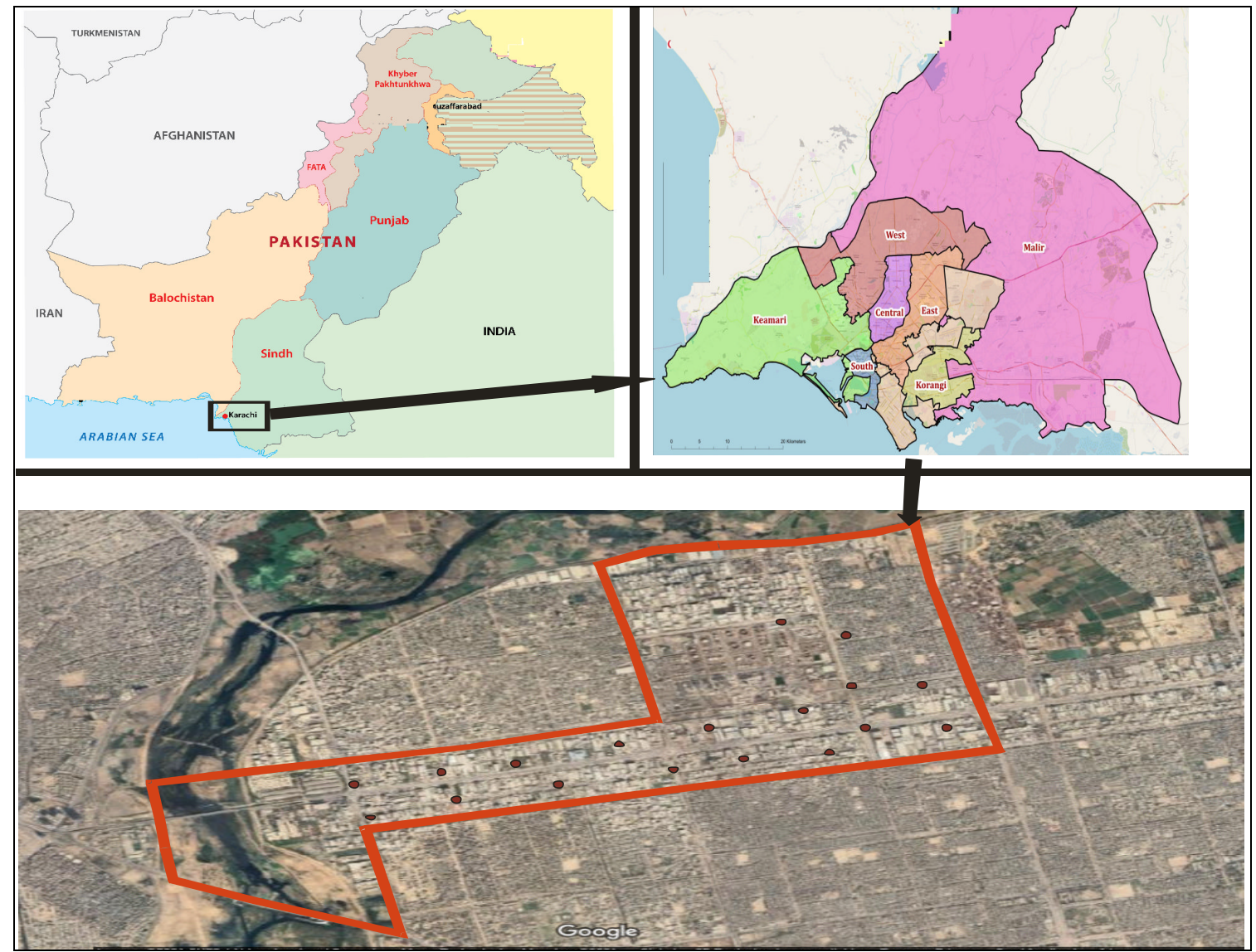

Figure 1. The location area of the research study (Korangi industrial estate, Karachi)

\section{Statistical Analysis}

MS Excel and Minitab version 11.12 were used for initial data recording, graphical presentation, and statistical analysis.

\section{Chemical Indices}

Nemerow's pollution index (NPI)

The NPI is enunciated by name that is also called the raw pollution index [19]. According to this index

$$
\mathrm{NPI}=\frac{c}{2}
$$

Here, $\quad C_{i}=$ experimental concentration of $i^{\text {th }}$ factor and $\mathrm{L}_{\mathrm{i}}=$ allowable limit of $\mathrm{i}^{\text {th }}$ factor.
The NPI must be less than or equal to one [19].

\section{The pollution load index (PLI)}

The PLI was employed for determining the degree of pollution. The value of PLI less than one shows no pollution, whereas higher than one shows pollution.

Higher PLI values indicate high noticeable input from an anthropogenic source, and lower PLI values indicate no appreciable input. The amount of contamination in estuarine sediments was calculated by using formulae are as follow,

$$
\mathrm{CF}=\frac{\mathrm{C}_{\text {metal }}}{\mathrm{C}_{\text {background }}}
$$


$\mathrm{PLI}=\mathrm{n} \sqrt{\left(\mathrm{CF}_{1} \times \mathrm{CF}_{2} \times \mathrm{CF}_{3} \times \ldots \ldots \ldots \mathrm{CF}_{\mathrm{n}}\right)}$

Here,

$\mathrm{CF}=$ contamination factor

$\mathrm{C}_{\text {metal }}=$ pollutant concentration in groundwater

$\mathrm{C}_{\text {background }}=$ background value for the metals.

\section{Geo accumulation index (Igeo)}

Contamination of heavy metal is calculated by $\mathrm{I}_{\text {geo }}$ method. It consists of seven grades, i.e., zero to six, which means the greater the number, the greater will be adulteration, calculated as:

$$
\mathrm{I}_{\text {geo }}=\log _{2} \frac{\zeta_{\mathrm{II}}}{=\mathrm{E}_{\mathrm{n}}}
$$

Here,

$\mathrm{C}_{\mathrm{n}}=$ concentration of metal in the enriched samples

$\mathrm{B}_{\mathrm{n}}=$ background value

$1.5=\mathrm{a}$ factor that minimizes the influence of positive variation in background values.

\section{Results and Discussion \\ Heavy Metals Examination}

The impact of anthropogenic heavy metal pollution was evaluated using NPI, PLI, and $\mathrm{I}_{\text {geo }}$ at 18 sampling sites of KIE. The current study indicates that these methods are convenient and valuable for the determination of contamination in groundwater.

Descriptive statistical analysis of heavy metals values generated and presented in Table 1. This data was compared with National Environmental Quality Standard, Pakistan (NEQS) and World Health Organization standards (WHO) in Table 2 [20]. The Fe range was 165 to $770 \mu \mathrm{g} . \mathrm{L}^{-1}$ with a mean value of $355 \mu \mathrm{g} . \mathrm{L}^{-1}$. Similarly, the range for $\mathrm{Zn}$ was found to be 385 to 1672 $\mu \mathrm{g} . \mathrm{L}^{-1}$ with $694 \mu \mathrm{g} . \mathrm{L}^{-1}$ as a mean value. Contents of $\mathrm{Cu}, \mathrm{Pb}, \mathrm{Cr}$, and $\mathrm{Ni}$ in $\mu \mathrm{g} . \mathrm{L}^{-1}$ were estimated in the range of 1 to 141,7 to 33,4 to 46 , and 2 to 13, respectively. Their mean values were $39,13,9$ and $6 \mu \mathrm{g} . \mathrm{L}^{-1}$, respectively. A critical study of Tables 1- 2 and Fig. 2 revealed that nine and five groundwater samples have higher concentrations set by WHO and NEQS for Fe $\left(300 \mu \mathrm{g} . \mathrm{L}^{-1}\right)$ and $\mathrm{Pb}\left(10 \mu \mathrm{g} . \mathrm{L}^{-1}\right)$, respectively.

Table 1. Heavy metal concentration in groundwater of Korangi industrial estate, Karachi.

\begin{tabular}{|c|c|c|c|c|c|c|}
\hline \multirow{2}{*}{$\begin{array}{c}\text { Samples } \\
\text { No. }\end{array}$} & $\mathbf{F e}$ & $\mathbf{Z n}$ & $\mathbf{C u}$ & $\mathbf{P b}$ & $\mathrm{Cr}$ & $\mathrm{Ni}$ \\
\hline & \multicolumn{6}{|c|}{$\mu g . L^{-I}$} \\
\hline $\mathrm{GW}_{1}$ & 199 & 492 & 73 & 09 & 09 & 07 \\
\hline $\mathrm{GW}_{2}$ & 320 & 628 & 19 & 10 & 11 & 05 \\
\hline $\mathrm{GW}_{3}$ & 187 & 407 & 16 & 26 & 11 & 07 \\
\hline $\mathrm{GW}_{4}$ & 196 & 495 & 21 & 08 & 15 & 08 \\
\hline $\mathrm{GW}_{5}$ & 562 & 392 & 131 & 33 & 46 & 11 \\
\hline $\mathrm{GW}_{6}$ & 631 & 1285 & 01 & 08 & 11 & 13 \\
\hline $\mathrm{GW}_{7}$ & 246 & 399 & 15 & 08 & 08 & 07 \\
\hline $\mathrm{GW}_{8}$ & 770 & 1023 & 141 & 26 & 07 & 06 \\
\hline $\mathrm{GW}_{9}$ & 165 & 473 & 19 & 08 & 04 & 06 \\
\hline $\mathrm{GW}_{10}$ & 253 & 561 & 18 & 27 & 06 & 07 \\
\hline $\mathrm{GW}_{11}$ & 209 & 396 & 35 & 08 & 04 & 06 \\
\hline $\mathrm{GW}_{12}$ & 286 & 1672 & 37 & 09 & 06 & 04 \\
\hline $\mathrm{GW}_{13}$ & 253 & 1617 & 23 & 15 & 07 & 08 \\
\hline $\mathrm{GW}_{14}$ & 358 & 385 & 32 & 07 & 04 & 02 \\
\hline $\mathrm{GW}_{15}$ & 361 & 583 & 38 & 08 & 05 & 04 \\
\hline $\mathrm{GW}_{16}$ & 433 & 506 & 31 & 07 & 04 & 03 \\
\hline $\mathrm{GW}_{17}$ & 308 & 638 & 43 & 08 & 06 & 03 \\
\hline $\mathrm{GW}_{18}$ & 647 & 546 & 13 & 07 & 07 & 04 \\
\hline $\mathrm{MAC}^{1}$ & 300 & 3000 & 2000 & 10 & 50 & 20 \\
\hline
\end{tabular}

Table 2. Descriptive statistics of heavy metals in groundwater of Korangi industrial estate, Karachi.

\begin{tabular}{|c|c|c|c|c|c|c|}
\hline Metal & $\mathbf{N}$ & Minimum & Maximum & Mean & $\begin{array}{c}\text { Std. } \\
\text { Error }\end{array}$ & $\begin{array}{c}\text { Std. } \\
\text { Deviation }\end{array}$ \\
\hline & & & & $\mu g . L^{-I}$ & & \\
\hline $\mathrm{Fe}$ & 18 & 165 & 770 & 354.67 & 42.73 & 181.30 \\
\hline $\mathrm{Zn}$ & 18 & 385 & 1672 & 694.33 & 97.93 & 415.50 \\
\hline $\mathrm{Cu}$ & 18 & 01 & 141 & 39.20 & 9.08 & 38.54 \\
\hline $\mathrm{Pb}$ & 18 & 07 & 33 & 12.90 & 2.03 & 8.62 \\
\hline $\mathrm{Cr}$ & 18 & 04 & 46 & 9.50 & 2.26 & 9.60 \\
\hline $\mathrm{Ni}$ & 18 & 02 & 13 & 6.17 & 0.66 & 2.80 \\
\hline
\end{tabular}




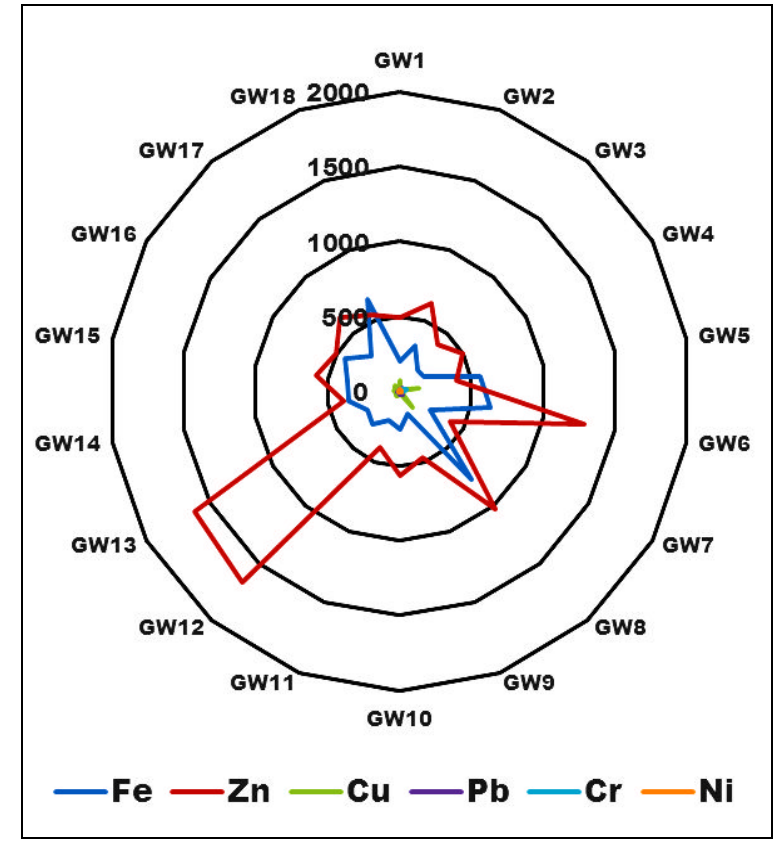

Figure 2. Heavy metals concentration in different sampling points of Korangi industrial estate, Karachi

Table 3 shows the correlation analysis between heavy metals in the groundwater of the study area. $\mathrm{Fe}$ and $\mathrm{Cu}$ showed a strong correlation with $\mathrm{Ni}(\mathrm{p}<0.5)$ whereas $\mathrm{Zn}$ had significant correlation with $\mathrm{Cr}(\mathrm{p}<0.05), \mathrm{Cu}$ and $\mathrm{Pb}(\mathrm{p}<0.01)$. In the study area, a higher correlation between parameters indicates that these elements are moving together in groundwater from industrial sources [21]. This is possible because of the adsorption characteristic and redox condition between these variables [22].

Many researchers around the world have carried out groundwater quality in terms of heavy metals (Table 4). The current study shows that heavy metal in the groundwater of the study area follows the order $\mathrm{Zn}>\mathrm{Fe}>\mathrm{Pb}$. The concentrations of heavy metals in groundwater are extremely variable and dependent on many factors. Land use and soil geochemistry are important factors for metal pollution in groundwater. The trace metals are not easily degradable as other organic pollutants [23]; thus, they persist longer, can infiltrate groundwater, tend to accumulate, involved in absorption, chemical combination, and complex formation [24].

Table 3. Correlation among tested heavy metals in groundwater of Korangi industrial estate, Karachi.

\begin{tabular}{ccccccc}
\hline & $\mathbf{F e}$ & $\mathbf{Z n}$ & $\mathbf{C u}$ & $\mathbf{P b}$ & $\mathbf{C r}$ & $\mathbf{N i}$ \\
\hline $\mathrm{Fe}$ & 1 & & & & & \\
$\mathrm{Zn}$ & 0.413 & 1 & & & & \\
$\mathrm{Cu}$ & 0.051 & $0.929^{* *}$ & 1 & & & \\
$\mathrm{~Pb}$ & 0.341 & $0.918^{* *}$ & 0.013 & 1 & & \\
$\mathrm{Cr}$ & 0.300 & $0.534^{*}$ & 0.026 & 0.011 & 1 & \\
$\mathrm{Ni}$ & $0.524^{*}$ & 0.449 & $0.655^{*}$ & 0.092 & 0.012 & 1 \\
\hline
\end{tabular}

*Correlation is significant at the 0.05 level $* *$ Correlation is significant at the 0.01 level

Table 4. Comparison of current investigation with past studies

\begin{tabular}{lccccc}
\hline \multirow{2}{*}{ Metals } & $\begin{array}{c}\text { Current } \\
\text { study }\end{array}$ & $\begin{array}{c}\text { Lofti } \\
{[25]}\end{array}$ & $\begin{array}{c}\text { Belkhiri } \\
{[\mathbf{2 6}]}\end{array}$ & $\begin{array}{c}\text { Singh } \\
{[27]}\end{array}$ & WHO \\
\cline { 2 - 6 } & & \multicolumn{5}{c}{$\boldsymbol{\mu g . \boldsymbol { L } ^ { - 1 }}$} \\
$\mathrm{Fe}$ & 355 & 120 & - & 250 & 300 \\
$\mathrm{Zn}$ & 694 & 770 & 148 & 10000 & 3000 \\
$\mathrm{Cu}$ & 39 & 630 & 241 & 300 & 2000 \\
$\mathrm{~Pb}$ & 13 & 01 & 87 & 00 & 10 \\
$\mathrm{Cr}$ & 10 & 04 & - & 00 & 50 \\
$\mathrm{Ni}$ & 06 & 00 & - & 30 & 20 \\
\hline
\end{tabular}

\section{Chemical Indices}

The NPI results revealed that only a few sampling points showed moderate to severe pollution problems, and their NPI values are greater than one (Table 5) [28]. It is used to measure the severity and variation of pollution in the groundwater. Results indicated that the metals' contamination factor (CF) such as $\mathrm{Zn}, \mathrm{Cu}, \mathrm{Cr}$, and $\mathrm{Ni}$ in the study area is less than one. Whereas $\mathrm{CF}$ values of $\mathrm{Fe}$ and $\mathrm{Pb}$ are higher than one, it indicates that groundwater of the study area is contaminated concerning these metal ions, perhaps due to the influence of industrial activity and anthropogenic sources [29, 30]. The PLI values of all the sampling locations of the study area were found to be generally low $(<1)$. The chemical indices results show the difference in insensitivity towards the groundwater pollutant. These values 
confirmed that the groundwater of the study area is facing environmental pollution for $\mathrm{Fe}$ and $\mathrm{Pb}$. These can be due to the increased release rate of untreated industrial effluent to ground and surface water [31].

The degree of pollution is measured quantitatively by $\mathrm{I}_{\text {geo }}$ in groundwater [32]. The results of $I_{\text {geo }}$ showed that groundwater in the study area was uncontaminated to moderately contaminate regarding $\mathrm{Fe}$ and $\mathrm{Pb}$ in a few sampling points. $\mathrm{I}_{\text {geo }}$ value in the case of $\mathrm{Zn}$, $\mathrm{Cu}, \mathrm{Cr}$, and $\mathrm{Ni}$ is less than one, revealing no contamination for these metals' ions in the groundwater of KIE (Table 6).
The concentrations of $\mathrm{Fe}$ and $\mathrm{Pb}$ were found higher in a few groundwater samples in Korangi industrial estate, exceeding WHO and NEQS guidelines. The higher concentration of $\mathrm{Fe}$ in KITE may be due to geological origin as well as the number of factors such as; steel industry, rusting of iron scrapes and corrosion of $\mathrm{Fe}$ containing metals are responsible for the same [33, 34]. The higher value of $\mathrm{Pb}$ may be attributed to fuel additives and also present in coal which is used as fuel in many industries $[35,36]$. It is inferred from the results obtained from different chemical indices applied to evaluate the groundwater quality in the study area closely in agreement with each other.

Table 5. NPI and PLI values of groundwater samples of KIE.

\begin{tabular}{|c|c|c|c|c|c|c|c|c|}
\hline \multirow{2}{*}{ Samples } & \multicolumn{6}{|c|}{$\mathrm{CF}^{1}$} & \multirow{2}{*}{$\mathbf{P L I}^{2}$} & \multirow{2}{*}{$\mathbf{N P I}^{3}$} \\
\hline & $\mathrm{Fe}$ & $Z n$ & $\mathrm{Cu}$ & $P b$ & $C r$ & $N i$ & & \\
\hline $\mathrm{GW}_{1}$ & 0.663 & 0.164 & 0.037 & 0.9 & 0.18 & 0.35 & 0.25 & 0.382 \\
\hline $\mathrm{GW}_{2}$ & 1.067 & 0.209 & 0.009 & 1.0 & 0.22 & 0.25 & 0.22 & $0.45 \mathrm{~s}$ \\
\hline $\mathrm{GW}_{3}$ & 0.623 & 0.136 & 0.008 & 2.6 & 0.22 & 0.35 & 0.23 & 0.656 \\
\hline $\mathrm{GW}_{4}$ & 0.653 & 0.165 & 0.01 & 0.8 & 0.3 & 0.4 & 0.22 & 0.388 \\
\hline $\mathrm{GW}_{5}$ & 1.873 & 0.131 & 0.066 & 3.3 & 0.92 & 0.55 & 0.55 & 1.14 \\
\hline $\mathrm{GW}_{6}$ & 2.103 & 0.428 & 0.0003 & 0.8 & 0.22 & 0.65 & 0.26 & 0.7 \\
\hline $\mathrm{GW}_{7}$ & 0.82 & 0.133 & 0.007 & 0.8 & 0.16 & 0.35 & 0.18 & 0.378 \\
\hline $\mathrm{GW}_{8}$ & 2.567 & 0.341 & 0.007 & 2.6 & 0.14 & 0.3 & 0.29 & 0.992 \\
\hline $\mathrm{GW}_{9}$ & 0.55 & 0.158 & 0.009 & 0.8 & 0.08 & 0.3 & 0.16 & 0.316 \\
\hline $\mathrm{GW}_{10}$ & 0.843 & 0.187 & 0.009 & 2.7 & 0.12 & 0.35 & 0.23 & 0.7 \\
\hline $\mathrm{GW}_{11}$ & 0.697 & 0.132 & 0.018 & 0.8 & 0.08 & 0.3 & 0.18 & 0.338 \\
\hline $\mathrm{GW}_{12}$ & 0.953 & 0.557 & 0.018 & 0.9 & 0.12 & 0.2 & 0.24 & 0.458 \\
\hline $\mathrm{GW}_{13}$ & 0.843 & 0.539 & 0.011 & 1.5 & 0.14 & 0.4 & 0.28 & 0.572 \\
\hline $\mathrm{GW}_{14}$ & 1.193 & 0.128 & 0.016 & 0.7 & 0.08 & 0.1 & 0.16 & 0.369 \\
\hline $\mathrm{GW}_{15}$ & 1.203 & 0.194 & 0.019 & 0.8 & 0.1 & 0.2 & 0.20 & 0.419 \\
\hline $\mathrm{GW}_{16}$ & 1.443 & 0.169 & 0.016 & 0.7 & 0.08 & 0.15 & 0.18 & 0.426 \\
\hline $\mathrm{GW}_{17}$ & 1.027 & 0.213 & 0.022 & 0.8 & 0.12 & 0.15 & 0.20 & 0.388 \\
\hline $\mathrm{GW}_{18}$ & 2.157 & 0.182 & 0.006 & 0.7 & 0.14 & 0.2 & 0.19 & 0.564 \\
\hline
\end{tabular}

${ }^{1}$ Contamination factor, ${ }^{2}$ Pollution load index, ${ }^{3}$ Nemerow's pollution index. 
Table 6. $\mathrm{I}_{\mathrm{geo}}$ values of groundwater samples of KIE.

\begin{tabular}{|c|c|c|c|c|c|c|}
\hline Samples & $\mathbf{F e}$ & Zn & $\mathbf{C u}$ & $\mathbf{P b}$ & $\mathrm{Cr}$ & $\mathbf{N i}$ \\
\hline $\mathrm{GW}_{1}$ & -1.181 & -3.204 & -5.379 & -0.739 & -3.069 & -2.107 \\
\hline $\mathrm{GW}_{2}$ & -0.493 & -2.850 & -7.328 & -0.587 & -2.778 & -2.594 \\
\hline $\mathrm{GW}_{3}$ & -1.271 & -3.478 & -7.577 & 0.796 & -2.778 & -2.107 \\
\hline $\mathrm{GW}_{4}$ & -1.203 & -3.195 & -7.183 & -0.91 & -2.329 & -1.913 \\
\hline $\mathrm{GW}_{5}$ & 0.322 & -3.533 & -4.533 & 1.141 & -0.707 & -1.452 \\
\hline $\mathrm{GW}_{6}$ & 0.489 & -1.814 & -12.329 & -0.91 & -2.778 & -1.210 \\
\hline $\mathrm{GW}_{7}$ & -0.874 & -3.507 & -7.67 & -0.91 & -3.239 & -2.107 \\
\hline $\mathrm{GW}_{8}$ & 0.777 & -2.144 & -4.426 & 0.796 & -3.433 & -2.329 \\
\hline $\mathrm{GW}_{9}$ & -1.452 & -3.261 & -7.328 & -0.91 & -4.243 & -2.329 \\
\hline $\mathrm{GW}_{10}$ & -0.834 & -3.014 & -7.406 & 0.851 & -3.656 & -2.107 \\
\hline $\mathrm{GW}_{11}$ & -1.11 & -3.518 & -6.443 & -0.91 & -4.243 & -2.329 \\
\hline $\mathrm{GW}_{12}$ & -0.656 & -1.433 & -6.363 & -0.739 & -3.656 & -2.917 \\
\hline $\mathrm{GW}_{13}$ & -0.834 & -1.482 & -7.051 & 0.0 & -3.433 & -1.913 \\
\hline $\mathrm{GW}_{14}$ & -.331 & -3.559 & -6.573 & -1.103 & -4.243 & -3.920 \\
\hline $\mathrm{GW}_{15}$ & -0.319 & -2.958 & -6.324 & -0.91 & -3.920 & -2.917 \\
\hline $\mathrm{GW}_{16}$ & -0.055 & -3.163 & -6.619 & -1.103 & -4.243 & -3.333 \\
\hline $\mathrm{GW}_{17}$ & -0.549 & -2.827 & -6.145 & -0.91 & -3.656 & -3.333 \\
\hline $\mathrm{GW}_{18}$ & 0.526 & -3.053 & -7.877 & -1.103 & -3.433 & -2.917 \\
\hline
\end{tabular}

\section{Conclusion}

In the current study, the impact of anthropogenic activities on heavy metal concentration in groundwater was evaluated using the chemical indices approaches. Overall results showed that groundwater quality in the study area had deteriorated mainly due to the contamination of $\mathrm{Fe}$ and $\mathrm{Pb}$. In a few samples, the concentrations of $\mathrm{Fe}$ and $\mathrm{Pb}$ are higher than WHO and NEQS guidelines. It is concluded that to minimize the risk to human health and the extent of heavy metal pollution, sincere efforts must be made, followed by an action plan to reduce $\mathrm{Fe}$ and $\mathrm{Pb}$ concentrations in groundwater. Consistent monitoring of groundwater around the study areas is also necessary.

\section{Acknowledgment}

We, the authors, are grateful to Hamdard University for providing lab facilities.

\section{Conflict of interest}

The authors declare that there is no conflict of interest.

\section{References}

1. D. Zilberman, B. Gordon, G. Hochman and J. Wesseler, Appl. Econ. Perspect. Policy, 40 (2018) 22. https://doi.org/10.1093/aepp/ppx051

2. P. Li, X. He, Y. Li and G. Xiang, Expos. Health, 11 (2019) 95.

https://link.springer.com/article/10.1007/ s12403-018-0278-X

3. X. Jia, D. O'Connor, D. Hou, Y. Jin, G. Li, C. Zheng, Y. S. Ok, D. C. Tsang and J. Luo, Sci. Total Environ., 672 (2019) 551.

10.1016/j.scitotenv.2019.03.457

4. V. G. Aschonitis, G. Castaldelli, N. Colombani and M. Mastrocicco, Arab. J. Geosci., 9 (2016) 1.

https://link.springer.com/article/10.1007/ $\underline{\text { s12517-016-2527-2 }}$ 
5. A. O. Talabi and T. J. Kayode, J. Water Resour. Prot., 11 (2019) 1. 10.4236/jwarp.2019.111001

6. H. Ali, E. Khan and I. Ilahi, J. Chem., Article ID 6730305 (2019) 1. https://doi.org/10.1155/2019/6730305

7. C. Singaraja, S. Chidambaram, K. Srinivasamoorthy, P. Anandhan and S. Selvam, Water Qual. Expos. Health, 7 (2015) 459.

https://link.springer.com/article/10.1007/ s12403-015-0162-X

8. F. J. Herbig, Cogent Social Sci., 5 (2019) 1701359.

https://doi.org/10.1080/23311886.2019.1 $\underline{701359}$

9. I. Dladla, F. Machete and K. Shale, Afr. J. Sci. Technol. Innov. Dev., 8 (2016) 475.

https://doi.org/10.1080/20421338.2016.1 224613

10. O. Fazal and P. J. Hotez, PLoS Negl. Trop. Dis., 14 (2020) e0008791.

https://doi.org/10.1371/journal.pntd.000 8791

11. A. Alamgir, M. A. Khan, J. Schilling, S. S. Shaukat and S. Shahab, Environ. Monit. Assess., 188 (2016) 78.

https://link.springer.com/article/10.1007 \%2Fs10661-015-5061-X

12. A. Khan and F. R. Qureshi, Asian J. Water Environ. Pollut., 15 (2018) 41. 10.3233/AJW-180004

13. A. Khan and A. EghbalBakhtiari, Int. J. Ground Sediment Water, 6 (2017) 248. http://ijgsw.comze.com/paper_PDF/2017 06/201706.pdf\#page $=4$

14. M. I. Nasir, H. N. Abbasi, A. Zubair and W. Ahmad, Pak. J. Sci. Ind. Res. A: Phys. Sci., 63 (2020) 130. https://doi.org/10.52763/PJSIR.PHYS.S CI.63.2.2020.130.138

15. W. Ahmad, A. Zubair, H. N. Abbasi land M. I. Nasir, Pak. J. Sci. Ind. Res. A: Phys. Sci., 64 (2021) 103.
https://doi.org/10.52763/PJSIR.PHYS.S CI.64.2.2021.103.109

16. A. U. Rahman, M. I. Sabir, British J. Appl. Sci. Technol., 14 (2016) 1.

https://www.researchgate.net/profile/Azi z-Ur-

Rahman/publication/290168650_Ecologi cal_Risk_Assessment_of_Ground_Wate r_Quality_of_Two_Industrial_Zones_of _Karachi_Pakistan/links/56950b0e08ae8 20ff07496dd/Ecological-Risk-

Assessment-of-Ground-Water-Qualityof-Two-Industrial-Zones-of-Karachi-

Pakistan.pdf

17. A. Siddique, N. Zaigham, K. Mallick, M. Mumtaz and S. Saied, Water Environ. Res., 80 (2008) 149-153. https://doi.org/10.2175/106143007X220 $\underline{824}$

18. W. E. Federation, A. Association, American Public Health Association (APHA): Washington, DC, USA, (2005).

http://www.just.edu.jo/CoursesAndLabs/ ENVIRONMENTAL\%20ANALYTICA L\%20CHEMISTRY_CHEM734/chem\% 20734.doc

19. A. Mohan, R. Singh, K. Pandey, V. Kumar and V. Jain, Ind. J. Environ. Prot., 27 (2007) 1031.

http://indiaenvironmentportal.org.in/files Assessment $\% 20$ of $\% 20$ water\%20quality $\% 20$ in\%20industrial\%20zone.pdf

20. F. Edition, WHO Chron., 38 (2011) 104. https://www.joinforwater.ngo/sites/defau 1t/files/library_assets/351_WHO_E13_g uidelines_drinking-water.pdf

21. M. Bodrud-Doza, A. T. Islam, F. Ahmed, S. Das, N. Saha and M. S. Rahman, Water Sci., 30 (2016) 19. https://doi.org/10.1016/j.wsj.2016.05.001

22. R. Ramesh, K. S. Kumar, S. Eswaramoorthi and G. Purvaja, Environ. Geol., 25 (1995) 126.

https://link.springer.com/article/10.1007/ $\underline{\text { BF00767869 }}$ 
23. L. Debernardi, D. A. De Luca, M. Lasagna, Environ. Geol., 55 (2008) 539. https://link.springer.com/article/10.1007/ s00254-007-1006-1

24. M. Kaur, A. Kumar, R. Mehra and I. Kaur, Environ. Geochem. Health, 42 (2020) 77.

https://link.springer.com/article/10.1007/ s10653-019-00294-7

25. S. Lotfi, M. Chakit and D. Belghyti, J. Health Pollut., 10 (2020).

https://doi.org/10.5696/2156-9614$\underline{10.26 .200603}$

26. L. Belkhiri, A. Tiri and L. Mouni, Assessment of Heavy Metals Contamination in Groundwater: A Case Study of the South of Setif Area, East Algeria, Book: Achievements and Challenges of Integrated River Basin Management, Dejan Komatina, Intech Open, (2018).

http://dx.doi.org/10.5772/intechopen.757 $\underline{34}$

27. V. Singh and C. S. Chandel, J. Environ. Sci. Eng., 48 (2006) 103.

https://citeseerx.ist.psu.edu/viewdoc/do wnload?doi=10.1.1.319.8667\&rep=rep1 \&type $=$ pdf

28. Y. Liu, Y. Hu, Y. Hu, Y. Gao and Z. Liu, J. Environ. Sci., 104 (2021) 40. https://doi.org/10.1016/j.jes.2020.10.021

29. R. V. Lakshmi, V. Raja, S. Chidambaram, C. P. Sekar and M. A. Neelakantan, Environ. Monit. Assess., 193 (2021) 1.

https://link.springer.com/article/10.1007/ s10661-021-09186-9
30. R. M. Kurakalva, G. Kuna, S. P. Vaiphei and S. S. Guddeti, Environ. Earth Sci., 80 (2021) 1.

https://link.springer.com/article/10.1007/ s12665-021-09661-z

31. J. Doummar and M. Aoun, Environ. Earth Sci., 77 (2018) 1.

https://link.springer.com/article/10.1007/ s12665-018-7536-X

32. R. A. I. Akoachere, T. A. Eyong, M. -C. P. Ngassam, R. N. Nkongho and S. O. Okpara, Open Access Library J., 6 (2019) 1. 10.4236/oalib.1105824

33. Z. $\mathrm{Yu}, \mathrm{L} . \mathrm{Hu}$ and I. M. Lo, Chemosphere, 216 (2019) 428.

https://doi.org/10.1016/j.chemosphere.20 $\underline{18.10 .125}$

34. V. Kumar, P. K. Bharti, M. Talwar, A. K. Tyagi and P. Kumar, Water Sci., 31 (2017) 44.

https://doi.org/10.1016/j.wsj.2017.02.003

35. N. Wang, X. Sun, Q. Zhao, Y. Yang and P. Wang, J. Hazard. Mater., 396 (2020) 122725.

https://doi.org/10.1016/j.jhazmat.2020.1 $\underline{22725}$

36. N. Soliman and A. Moustafa, J. Mater. Res. Technol., 9 (2020) 10235. https://doi.org/10.1016/j.jmrt.2020.07.04 $\underline{5}$ 